\title{
OBESITY AS A COMMON COMORBIDITY IN PATIENTS WITH DIABETES: OCCURRENCE BASED ON EATING HABITS AND OTHER DETERMINANTS IN WEST JAVA, INDONESIA
}

\author{
MELIZA SUHARTATIK, RATU AYU DEWI SARTIKA \\ Department of Public Health Nutrition, Faculty of Public Health, Universitas Indonesia, West Java, Indonesia. Email:m3l1z4@yahoo.com \\ Received: 05 October 2019, Revised and Accepted: 30 October 2019
}

ABSTRACT

Objective: The prevalence of obesity in individuals with diabetes mellitus (DM) is fairly high. It has been shown that obesity worsens insulin resistance and can elevate the risk for complications of diabetes. Therefore, this study aimed to assess the prevalence of obesity and to determine the factors that affect obesity in adults with DM.

Methods: This study used a cross-sectional design and included secondary data from the "Cohort Study of Risk Factors for Non-communicable Diseases." The study was conducted on adults with DM at Kebon Kelapa Village, West Java, in 2017, and the total sample obtained for analysis was 112 respondents.

Results: In this study, $62.5 \%$ of adults with DM were overweight or obese (body mass index $\geq 25 \mathrm{~kg} / \mathrm{m}^{2}$ ). Factors found to influence the incidence of obesity in adults with DM were sex and macronutrient intakes, namely, "over" energy intake, "over" carbohydrate intake, "over" fat intake, and "normal" protein intake. Risk of obesity was 3.15-fold higher in female than male participants with diabetes. The highest risk for increased obesity level in adults with diabetes was found in those with "over" fat intake (odds ratio, 8.33).

Conclusions: In adults with diabetes, the incidence of obesity is a trigger of complications. Therefore, to improve the quality of life of individuals with diabetes, attention must be given to managing their weight.

Keywords: Diabetes mellitus, Obesity, Prevalence, Risk factor.

(c) 2020 The Authors. Published by Innovare Academic Sciences Pvt Ltd. This is an open access article under the CC BY license (http://creativecommons. org/licenses/by/4. 0/) DOI: http://dx.doi.org/10.22159/ajpcr.2020.v13i1.35981

\section{INTRODUCTION}

Diabetes mellitus (DM) is a chronic disease that can lead to complications such as stroke, heart attack, nerve damage, kidney failure, vision loss, and leg amputation. People with DM and their families, as well as health systems and national economies, experience substantial economic loss as a result of diabetes and its complications, through direct medical costs and loss of work and wages [1]. According to the International Diabetes Federation, in 2017, among all countries, Indonesia ranked sixth in terms of diabetes prevalence, with a rate of 10 million adults with diabetes [2].

Most patients with type $2 \mathrm{DM}$ are obese [3]. Many studies have confirmed that obesity is associated with an increased risk of developing DM [4]. However, not much research has been conducted in people with DM who become obese. This study is very important because obesity can worsen insulin resistance and increase the development of diabetes complications, such as cardiovascular disease $[5,6]$. Diabetes with complication is the number one cause of death in Indonesia [7]. The objective of this study is to assess the prevalence of obesity and the factors that affect obesity in adults with DM at Kebon Kelapa Village, West Java.

\section{METHODS}

Ethical approvals to conduct the study were obtained from the Research and Community Engagement Ethical Committee, Faculty of Public Health, Universitas Indonesia. This study used a cross-sectional design and used secondary data from the "Cohort Study of Non-communicable Disease Risk Factors" conducted by the National Institute of Health Research and Development, Indonesian Ministry of Health in Kebon Kelapa Village, West Java, in 2017. The population in this study was taken from individuals with diabetes who enrolled in the cohort study in 2017 ( $n=174$; aged $>24$ years). Respondents who had a history of heart disease and/or stroke $(\mathrm{n}=19)$ and whose data were not available at the follow-up (missing data, $n=43$ ) were excluded from the study sample. Thus, the total number of individuals included in this study was 112 .

Obesity status was considered the dependent variable, assessed through a body mass index (BMI) of $27 \mathrm{~kg} / \mathrm{m}^{2}$ or higher. BMI is the ratio of weight-toheight squared $\left(\mathrm{kg} / \mathrm{m}^{2}\right)$ and is categorized as follows: Lean $\left(<18.5 \mathrm{~kg} / \mathrm{m}^{2}\right)$, normal $\left(18.5-25.0 \mathrm{~kg} / \mathrm{m}^{2}\right)$, overweight $\left(25.1-27.0 \mathrm{~kg} / \mathrm{m}^{2}\right)$, and obese $\left(\geq 27 \mathrm{~kg} / \mathrm{m}^{2}\right)$ [8]. The independent variables included sociodemographic characteristics (age, sex, level of education, income, and occupation), medication compliance, smoking habits, mental health status (assessed using a self-report questionnaire), macronutrient intake per day (energy, protein, carbohydrate, and fat), and physical activity (assessed using the Global Physical Activity Questionnaire version 2.0) [9].

Data on macronutrient intake were obtained using $24 \mathrm{~h}$ recall. The estimated energy requirements for adults with diabetes differ depending on body weight: $2300-2500 \mathrm{kcal}$ for lean, $1700-2100 \mathrm{kcal}$ for normal, and 1300-1500 kcal for overweight [10]. Other nutritional requirements for adults with diabetes are $10 \%-20 \%$ of total energy from protein, $45 \%$ to $65 \%$ of total energy from carbohydrates, and $20 \%$ to $25 \%$ of total energy from fat [11]. We categorized the nutritional intake as "deficit" (<90\%), "normal" (90\%-119\%), and "over" ( $\geq 120 \%)$ [12]. Chi-square tests were used to analyze data in the bivariate analyses.

\section{RESULTS}

\section{Characteristic of adults with DM}

The characteristics of adult with DM at Kebon Kelapa Village, West Java, in 2017 present in Tables 1 and 2, it is known that a large proportion $(62.5 \%)$ of adults with DM were overweight and obese. Most of the individuals with DM were 55-65 years old (42.9\%), female sex (67.9\%) had low education (60.7\%), low income (59.6\%), 
Table 1: Characteristics based on BMI and sociodemographic

\begin{tabular}{|c|c|c|}
\hline Variable & $\mathbf{n}$ & $\%$ \\
\hline \multicolumn{3}{|l|}{ BMI } \\
\hline Lean & 5 & 4.5 \\
\hline Normal & 37 & 33.0 \\
\hline Overweight & 26 & 23.2 \\
\hline Obese & 44 & 39.3 \\
\hline \multicolumn{3}{|l|}{ Age (years) } \\
\hline $25-34$ & 2 & 1.8 \\
\hline $35-44$ & 14 & 12.5 \\
\hline $45-54$ & 42 & 37.5 \\
\hline $55-65$ & 48 & 42.9 \\
\hline$>65$ & 6 & 5.4 \\
\hline \multicolumn{3}{|l|}{ Sex } \\
\hline Male & 36 & 32.1 \\
\hline Female & 76 & 67.9 \\
\hline \multicolumn{3}{|l|}{ Education level } \\
\hline High & 44 & 39.3 \\
\hline Low & 68 & 60.7 \\
\hline \multicolumn{3}{|l|}{ Income level } \\
\hline High (>median) & 65 & 59.6 \\
\hline Low $(\leq$ median $)$ & 44 & 40.4 \\
\hline \multicolumn{3}{|l|}{ Occupation } \\
\hline Driver & 2 & 1.8 \\
\hline Domestic workers & 51 & 45.5 \\
\hline College student & 2 & 1.8 \\
\hline Civil servants & 6 & 5.4 \\
\hline Entrepreneur & 32 & 28.6 \\
\hline Private employees & 9 & 8.0 \\
\hline Construction workers & 2 & 1.8 \\
\hline Unemployment & 8 & 7.2 \\
\hline
\end{tabular}

n: Number=112, BMI: Body mass index

Table 2: Characteristics based on nutrition intake and other variables

\begin{tabular}{|c|c|c|}
\hline Variable & $\mathbf{n}$ & $\%$ \\
\hline \multicolumn{3}{|c|}{ Energy intake (kcal/d) } \\
\hline Deficit & 32 & 28.6 \\
\hline Normal & 34 & 30.4 \\
\hline Over & 46 & 41.1 \\
\hline \multicolumn{3}{|c|}{ Protein intake (g/d) } \\
\hline Deficit & 15 & 13.4 \\
\hline Normal & 89 & 79.5 \\
\hline Over & 8 & 7.1 \\
\hline \multicolumn{3}{|c|}{ Carbohydrate intake (g/d) } \\
\hline Deficit & 21 & 18.8 \\
\hline Normal & 60 & 53.6 \\
\hline Over & 31 & 27.7 \\
\hline \multicolumn{3}{|l|}{ Fat intake $(\mathrm{g} / \mathrm{d})$} \\
\hline Deficit & 11 & 9.8 \\
\hline Normal & 35 & 31.3 \\
\hline Over & 66 & 58.9 \\
\hline \multicolumn{3}{|l|}{ Physical activity } \\
\hline High & 93 & 83.0 \\
\hline Moderate & 16 & 14.3 \\
\hline Low & 3 & 2.7 \\
\hline \multicolumn{3}{|c|}{ Medication compliance } \\
\hline Not compliance & 86 & 76.8 \\
\hline Compliance & 26 & 23.2 \\
\hline \multicolumn{3}{|l|}{ Smoking habit } \\
\hline Smoking & 56 & 50.0 \\
\hline Not smoking & 56 & 50.0 \\
\hline \multicolumn{3}{|c|}{ Mental health status } \\
\hline Not stressed & 94 & 83.9 \\
\hline Stressed & 18 & 16.1 \\
\hline
\end{tabular}

n: Number $=112$

and worked as domestic workers (45.5\%). Regarding macronutrient intake, $41.1 \%$ and $58.9 \%$ of the adults with diabetes were found to have "over" energy intake and "over" fat intake, respectively. Results for other characteristics also indicate that $65.2 \%$ of adults with diabetes engaged in "high" physical activity, $76.8 \%$ were noncompliant with DM medication, and $83.9 \%$ of adults with diabetes did not under stress conditions. As for smoking habits, the proportion of participants "not smoking" and those "smoking" was the same (50.0\%).

\section{Obesity risk factor in adults with DM}

The results of the bivariate analysis show that sex and macronutrient intake were the significant factors that determine the incidence of obesity in adults with diabetes. Risk of obesity was 3.15-fold higher in female than in male participants with diabetes. With regard to macronutrient intake, the highest risk of obesity was found in participants with "over" fat intake, which was 8.3-fold higher than for those with "deficit" fat intake. Table 3 presents the data for the risk factors for obesity among the adults with diabetes in this study.

\section{DISCUSSION}

In this study, $62.5 \%$ of adults with DM had a BMI $\geq 25 \mathrm{~kg} / \mathrm{m}^{2}$, indicating that they were overweight or obese. The prevalence of diabetes and obesity is on the rise worldwide. In some countries such as the United Kingdom, around $86 \%$ of patients with type 2 DM were found to be overweight or obese (BMI $25-40 \mathrm{~kg} / \mathrm{m}^{2}$ ). In the United States, a BMI of $25 \mathrm{~kg} / \mathrm{m}^{2}$ was found in $90 \%$ of patients with type 2 DM $[5,13]$. A strong relationship has been found between BMI and diabetes and insulin resistance $[3,14,15]$, but not all overweight or obese people will develop diabetes, and not all diabetic people are overweight or obese. The mechanism for explaining diabetic people become overweight or obese is the decreased glycosuria after improving blood sugar control, inhibition of the catabolism, the anabolic effect of insulin, protein anabolism, suppression of hepatic glucose production and gluconeogenesis, increased food intake, low physical activity, and hypoglycemia $[6,16,17]$.

Factors related to sex also have a strong relationship to the incidence of obesity in adults with diabetes: Women with diabetes are more obese than men with diabetes. Further analysis also reveals that with regard to age, in those $<45$ years, the incidence of obesity was higher in women with diabetes than in men with diabetes (57.1\% and $42.9 \%$, respectively); the same trend was seen in those aged $\geq 45$ years $(86.5 \%$ and $13.5 \%$, respectively). This clearly shows that body composition and fat deposition in sex differences contribute to diabetes risk. Men generally have more fat-free muscle compared with women. Women after menopause are at an increased risk of developing visceral obesity because the loss of estrogen. Estrogen is important regulators of body weight $[18,19]$.

In relation to macronutrient intake, the analysis shows a strong association between "over" energy intake and obesity in adults with diabetes. The mean energy intake of non-obese adults with diabetes with "over" intake was $2384 \pm 376 \mathrm{kcal} / \mathrm{d}$, lower than that for obese adults with diabetes $(2921 \pm 682 \mathrm{kcal} / \mathrm{d})$. There have been many studies prove that weight gain is driven mainly by energy intake exceeding energy expenditure $[20,21]$.

Protein intake analyses have shown that there is a strong association between daily "normal" protein intake and obesity in adults with diabetes. Mean "normal" protein intake in obese adults with diabetes is $56 \pm 16 \mathrm{~g} / \mathrm{d}$, which is lower than that of non-obese adults with diabetes $(60 \pm 19 \mathrm{~g} / \mathrm{d})$. On the other hand, "over" protein intake is not significantly related to the incidence of obesity in adults with diabetes. Dietary proteins influence body weight trough satiety, thermogenesis, energy efficiency, and body composition. In the studies lasting up to 1 year have shown the similar result that consumption of higher amounts of protein during dietary treatment for obesity resulted in greater weight loss than did consumption of lower amounts of protein [22,23].

Adults with diabetes with "over" carbohydrate intake have a 3.98fold higher risk of being obese compared with those with "deficit" carbohydrate intake. This result is in contrast to the results of a 
Table 3: Obesity risk factors in adults with DM

\begin{tabular}{|c|c|c|c|c|c|c|c|}
\hline \multirow[t]{3}{*}{ Variable } & \multicolumn{4}{|l|}{ Obese } & \multirow[t]{3}{*}{$p$ value } & \multirow[t]{3}{*}{ OR } & \multirow[t]{3}{*}{$(95 \% \mathrm{CI})$} \\
\hline & \multicolumn{2}{|l|}{ No } & \multicolumn{2}{|l|}{ Yes } & & & \\
\hline & $n=68$ & $\%$ & $n=44$ & $\%$ & & & \\
\hline \multicolumn{8}{|l|}{ Age (years) } \\
\hline $25-34$ & 1 & 50.0 & 1 & 50.0 & & & \\
\hline $35-44$ & 8 & 57.1 & 6 & 42.9 & 0.85 & 0.75 & $0.04-14.58$ \\
\hline $45-54$ & 24 & 57.1 & 18 & 42.9 & 0.84 & 0.75 & $0.04-12.82$ \\
\hline $55-65$ & 31 & 64.6 & 17 & 35.4 & 0.68 & 0.55 & $0.03-9.33$ \\
\hline$>65$ & 4 & 66.7 & 2 & 33.3 & 0.68 & 0.50 & $0.02-12.0$ \\
\hline \multicolumn{8}{|l|}{ Sex } \\
\hline Male & 28 & 77.8 & 8 & 22.2 & $0.02^{*}$ & 3.15 & $1.27-7.79$ \\
\hline Female & 40 & 52.6 & 36 & 47.4 & & & \\
\hline \multicolumn{8}{|l|}{ Education level } \\
\hline High & 26 & 59.1 & 18 & 40.9 & 0.93 & 0.89 & $0.41-1.94$ \\
\hline Low & 42 & 61.8 & 26 & 38.2 & & & \\
\hline \multicolumn{8}{|l|}{ Income level } \\
\hline High & 38 & 58.5 & 27 & 41.5 & 0.73 & 0.80 & $0.37-1.77$ \\
\hline Low & 28 & 63.6 & 16 & 36.4 & & & \\
\hline \multicolumn{8}{|c|}{ Energy intake (kcal/d) } \\
\hline Deficit & 25 & 78.1 & 7 & 21.9 & ref & 1 & \\
\hline Normal & 21 & 61.8 & 13 & 38.2 & 0.15 & 2.21 & $0.75-6.55$ \\
\hline Over & 22 & 47.8 & 24 & 52.2 & $0.01^{*}$ & 3.90 & $1.41-10.79$ \\
\hline \multicolumn{8}{|c|}{ Protein intake (g/d) } \\
\hline Deficit & 13 & 86.7 & 2 & 13.3 & ref & 1 & \\
\hline Normal & 50 & 56.2 & 39 & 43.8 & $0.04^{*}$ & 5.07 & $1.08-23.80$ \\
\hline Over & 5 & 62.5 & 3 & 37.5 & 0.20 & 3.90 & $0.49-30.76$ \\
\hline \multicolumn{8}{|c|}{ Carbohydrate intake (g/d) } \\
\hline Deficit & 17 & 81.0 & 4 & 19.0 & ref & 1 & \\
\hline Normal & 35 & 58.3 & 25 & 41.7 & 0.07 & 3.05 & $0.91-10.12$ \\
\hline Over & 16 & 51.6 & 15 & 48.4 & $0.04^{*}$ & 3.98 & $1.09-14.58$ \\
\hline \multicolumn{8}{|l|}{ Fat intake $(\mathrm{g} / \mathrm{d})$} \\
\hline Deficit & 10 & 90.9 & 1 & 9.1 & ref & 1 & \\
\hline Normal & 22 & 62.9 & 13 & 37.1 & 0.11 & 5.91 & $0.68-51.60$ \\
\hline Over & 36 & 54.5 & 30 & 45.5 & $0.05^{*}$ & 8.33 & $1.01-68.87$ \\
\hline \multicolumn{8}{|l|}{ Physical activity } \\
\hline High & 57 & 61.3 & 36 & 38.7 & ref & 1 & \\
\hline Moderate & 10 & 62.5 & 6 & 37.5 & 0.93 & 0.95 & $0.32-2.84$ \\
\hline Low & 1 & 33.3 & 2 & 66.7 & 0.35 & 3.17 & $0.28-36.20$ \\
\hline \multicolumn{8}{|l|}{ Smoking habit } \\
\hline Not smoking & 36 & 64.3 & 20 & 35.7 & 0.56 & 1.35 & $0.63-2.89$ \\
\hline Smoking & 32 & 57.1 & 24 & 42.9 & & & \\
\hline \multicolumn{8}{|c|}{ Mental health status } \\
\hline Not stressed & 58 & 61.7 & 36 & 38.3 & 0.82 & 1.29 & $0.47-3.57$ \\
\hline \multirow{2}{*}{\multicolumn{8}{|c|}{ Medication compliance }} \\
\hline & & & & & & & \\
\hline Not compliance & 49 & 57.0 & 37 & 43.0 & 0.21 & 0.49 & $0.19-1.28$ \\
\hline Compliance & 19 & 73.1 & 7 & 26.9 & & & \\
\hline
\end{tabular}

systematic review/meta-analysis study conducted by Sartorius et al. that showed that a higher proportion of carbohydrates in unrestricted diets does not increase obesity levels. However, in other studies shown a positive association between certain dietary carbohydrates (such as sugar-sweetened beverages) and weight gain. Further studies that specifically classify types of carbohydrate intake are needed [24-26].

The highest risk of causing obesity in adults with diabetes is "over" fat intake compared with other macronutrients (odds ratio, 8.33). Based on the National Health Survey 2013, West Java is one of the five provinces with the highest consumption of fat and cholesterol and also fried food above the national average. Finding reported that individual consuming fried food which containing trans fatty acid has a higher risk of lipid profile abnormality, which was likely associated with obesity $[27,28]$. A high-fat diet also is one of the main causes of the development of obesity. Foods high in fat are highly palatable and seem to induce a relatively weak sense of satiety. A high-fat diet also results in altered microbiota composition and enhancement in fat storage [29-31]. Obesity management may be beneficial in the treatment of people with
DM. The modest and sustained weight loss will be beneficial not only in terms of glycemic control but also other health benefits associated with complications of diabetes $[6,32]$.

\section{CONCLUSIONS}

This study found that the incidence of obesity in adults with DM was high and that the factors with the highest effect on the prevalence of obesity in adults with DM were having a high-fat intake. Therefore, because the incidence of obesity in adults with diabetes is a trigger of complications, to improve the quality of life of people with diabetes, attention must be given to manage their weight.

\section{ACKNOWLEDGMENT}

We would like to show our appreciation to the Directorate of Research and Community Service - Universitas Indonesia for financial support to conduct this study and to the National Institute of Health Research and Development, Indonesian Ministry of Health for the opportunity to use data from the "Cohort Study of Non-communicable Diseases." 


\section{AUTHORS' CONTRIBUTIONS}

The authors declare that this work was done by the authors named in this article.

\section{CONFLICTS OF INTEREST}

The authors declare that they have no conflicts of interest.

\section{REFERENCES}

1. World Health Organization. Global Report on Diabetes. Vol. 978. WHO Library Cataloguing-in-Publication Data; 2016. Available from: http:// www.who.int/about/licensing.

2. International Diabetes Federation. IDF Diabetes Atlas. $8^{\text {th }}$ ed. Brussels, Belgium: International Diabetes Federation; 2017. Available from: http://www.diabetesatlas.org/resources/2017-atlas.html.

3. Eckel RH, Kahn SE, Ferrannini E, Goldfine AB, Nathan DM, Schwartz MW, et al. Obesity and Type 2 diabetes: What can be unified and what needs to be individualized? Diabetes Care 2011;34:1424-30.

4. Sapkota NK, Swain KC. Obesity, Type-2 diabetes mellitus and its management. Innov J Health Sci 2016;5:17-20.

5. Bramante CT, Lee CJ, Gudzune KA. Treatment of obesity in patients with diabetes. Diabetes Spectr 2017;30:237-43.

6. Wilding JP. The importance of weight management in Type 2 diabetes mellitus. Int J Clin Pract 2014;68:682-91.

7. World Health Organization. Diabetes Fakta Dan Angka [Diabetes Facts and Numbers]. Epidemiological Situation; 2015. p. 2. Available from: http://www.who.int/leishmaniasis/burden/en.

8. Ministry of Health Republic of Indonesia. Pedoman Praktis Memantau Status Gizi Orang Dewasa [Practical Guidelines for Monitoring Adult Nutritional Status]. Indonesia: Ministry of Health Republic of Indonesia; 2011. p. 7.

9. World Health Organization. Global Physical Activity questionnaire: GPAQ Version 2.0. Dep Chronic Dis Heal Promot; 2009. Available from: http://www.who.int/chp/steps/GPAQ_EN.pdf?ua=1.

10. Soegondo S, Soewondo P, Subekti I. Penatalaksanaan Diabetes Melitus Terpadu [Integrated Diabetes Mellitus Management]: Panduan Penatalaksanaan Diabetes Melitus Bagi Dokter dan Edukator. Jakarta: Balai Penerbitan FKUI; 2011. p. 346.

11. PERKENI. Konsensus Pengelolaan dan Pencegahan Diabetes Melitus Type 2 di Indonesia 2015 [Consensus on the Management and Prevention of Type 2 Diabetes Mellitus in Indonesia 2015]. Indonesia: PB PERKENI; 2015. p. 82.

12. Gibson RS. Principles of Nutritional Assessment. $2^{\text {nd }}$ ed. US, Europe: Oxford University Press; 2005. p. 907.

13. Al-Sharafi BA, Gunaid AA. Prevalence of obesity in patients with Type 2 diabetes mellitus in Yemen. Int J Endocrinol Metab 2014;12:1-5.

14. Al-Goblan AS, Al-Alfi MA, Khan MZ. Mechanism linking diabetes mellitus and obesity. Diabetes Metab Syndr Obes 2014;7:587-91.

15. Onwubuya EI, Ukibe NR, Kalu OA, Emelumadu OF, Monago IN,
Ukibe SN. Prevalence of overweight and obesity and assessment of lipid profile and fasting blood glucose levels among female premedical students at Nnamdi Azikiwe University, Nnewi Campus, Nigeria. Asian J Pharm Clin Res 2018;11:481-6.

16. Van Gaal L, Scheen A. Weight management in Type 2 diabetes: Current and emerging approaches to treatment. Diabetes Care 2015;38:1161-72.

17. Jacob AN, Salinas K, Adams-Huet B, Raskin P. Weight gain in Type 2 diabetes mellitus. Diabetes Obes Metab 2007;9:386-93.

18. Meyer MR, Clegg DJ, Prossnitz ER, Barton M. Obesity, insulin resistance and diabetes: Sex differences and role of oestrogen receptors. Acta Physiol(Oxf) 2011;203:259-69.

19. Kautzky-Willer A, Harreiter J, Pacini G. Sex and gender differences in risk, pathophysiology and complications of Type 2 diabetes mellitus. Endocr Rev 2016;37:278-316.

20. Romieu I, Dossus L, Barquera S, Blottière HM, Franks PW, Gunter M, et al. Energy balance and obesity: What are the main drivers? Cancer Causes Control 2017;28:247-58.

21. Khemka VK, Banerjee A. Metabolic risk factors in obesity and diabetes mellitus: Implications in the pathogenesis and therapy. Integr Obes Diabetes 2017;3:1-4

22. Keller U. Dietary proteins in obesity and in diabetes. Int J Vitam Nutr Res 2011;81:125-33

23. Drummen M, Tischmann L, Gatta-Cherifi B, Adam T, WesterterpPlantenga M. Dietary protein and energy balance in relation to obesity and co-morbidities. Front Endocrinol (Lausanne) 2018;9:1-13.

24. Sartorius K, Sartorius B, Madiba TE, Stefan C. Does high-carbohydrate intake lead to increased risk of obesity? A systematic review and metaanalysis. BMJ Open 2018;8:1-9.

25. Ma Y, Olendzki B, Chiriboga D, Hebert JR, Li Y, Li W, et al. Association between dietary carbohydrates and body weight. Am J Epidemiol 2005;161:359-67.

26. Malik VS, Schulze MB, Hu FB. Intake of sugar-sweetened beverages and weight gain: A systematic review. Am J Clin Nutr 2006;84:274-88.

27. Ministry of Health Republic of Indonesia. Riset Kesehatan Dasar (National Health Survey) 2013. Indonesia: Ministry of Health Republic of Indonesia; 2013. p. 1-303.

28. Sudargo T, Sari FT, Naomi ND. The correlation of obesity, smoking, fried foods consumption pattern and food intake with lipid profile in civil servant in Yogyakarta, Indonesia. Int J Community Med Public Health 2017;4:690-7.

29. Lee CY. The effect of high-fat diet-induced pathophysiological changes in the gut on obesity: What should be the ideal treatment. Clin Transl Gastroenterol 2013;4:e39-8.

30. Jung $\mathrm{CH}$, Choi KM. Impact of high-carbohydrate diet on metabolic parameters in patients with Type 2 diabetes. Nutrients 2017;9:1-20.

31. Kesh SB, Sarkar D, Manna K. High-fat diet-induced oxidative stress and its impact on metabolic syndrome: A review. Asian J Pharm Clin Res 2016;9:47-52.

32. American Diabetes Association. 6. Obesity management for the treatment of Type 2 diabetes. Diabetes Care 2016;39:S47-51. 